\title{
Effect of Number of Tillers Per Hill on Quality Production of Palmarosa (Cympopogon Martinii)
}

\author{
HAILU GARKEBO MOLA (MSc) \\ WEROTAW SISAY YESHITILA (BSc) \\ Ethiopian Institute of Agricultural Research, Wondo Genet Agricultural Research Center
}

\begin{abstract}
A study was conducted to assess the role of number of tillers on quality production of palmarosa grass varieties. A field experiment consisting of two varieties (Wg-tejisar-I and Wg-tejisar-II) and four number of tillers $(3,5,7$ and 9) in RCBD with three replications. There were two harvesting time with in three months interval all parameters were taken during the course of field experiments. Even if no significant difference the results of the experiment study revealed that, the palmarosa variety Wg-tejisar-II performed better than the Wg-tejisar-I in respect of some growth and yield parameters. At the first cycle, the effects of planting 7 and 3 tillers on the two varieties have better plant height, number of leaves, number of tillers. Significantly maximum fresh biomass and oil yield were harvested by planting WG-Tejsar-II variety with seven tillers was $83.88 \mathrm{Qt} / \mathrm{ha}$ and $115.49 \mathrm{~kg} / \mathrm{ha}$ which have no biomass difference with planting three number of tillers $(70.52 \mathrm{Qt} / \mathrm{ha})$ and $(102.34 \mathrm{~kg} / \mathrm{ha})$ respectively. The heights oil content recorded at the plot which contain WG-Tejsar-II variety with planting three tillers $(1.79 \%)$ and next to that planting WG-Tejsar-II variety with nine number of tillers (1.55\%). The data was recorded six months after planting, the plant height, number of leaves and number of tillers were not affected by varying the level of tillers number but the value indicated that planting seven tillers for the two palmarosa varieties shows the better result relative to the rest of configured levels. The highest biomass was recorded by planting WGTejsar-II with 7 number of tillers (33.07 Qt/ha) next to planting WG-Tejsar-II with 3 number of tillers (49.59 Qt/ha). The analysis indicated that non-significant oil volume of WG-Tejsar-II at the second cycle of data collection was observed. In general, planting 3 tillers for WG-Tejsar-I and 7 tillers for WG-Tejsar-II variety at a time have an advantage to get a greater quality production of palmarosa.
\end{abstract}

Keywords: Cymbopogon martinii, tiller number, variety, biomass, oil content and essential oil and survival count. DOI: $10.7176 / \mathrm{JBAH} / 10-17-04$

Publication date:September $30^{\text {th }} 2020$

\section{Introduction}

Background and Justification

Aromatic (Aroma Producing) plants are those plants which produce a certain type of aroma. Their aroma is due to the presence of some kind of essential oil with chemical constituents that contain at least one benzene ring in their chemical configuration. Among the aromatic grasses, the genus Cymbopogon consists of about 100 species, distributed mainly in the tropical region of Africa and South East India (Takankhar et al., 2017). It was an indigenous plant found in large tracts in open dry scrub forests of India. Palmarosa is one of the perennial aromatic plants grown for its herbal and essential oil yield. It belongs to family Poaceae. Palma rosa is a hardy plant and can grow in varying altitude right from sea level. However, it does not withstand stagnant water (Takankhar et al., 2017).

The annual production of palmarosa in India is estimated to be 70-80 tones which are mostly obtained from wild sources (i.e. forests). Successful cultivation of palmarosa can also be done on problematic soils such as saline and alkali soils, poor fertile soils, sloppy lands and soils with high proportions of gravels and coarse sand (Takankhar et al., 2017). Palmarosa is cultivated both as rain fed and irrigated crop in several tropical and subtropical parts of India. It requires exposed sunlight and does not perform well under shady situations. Palmarosa prefers a well-drained soil (Gingade et al., 2015).

The chemical nature of aromatic substances may be due to a variety of complex chemical compounds. These plants have made a good contribution to the development of ancient Indian material medics. In recent years, there has been a tremendous growth of interest in plant-based drugs, pharmaceuticals, perfumery products, cosmetics and aroma compounds used in food flavors and fragrances and natural colors in the world. Essential oil from flower petals of Palmarosa is used for gargles in throat infection, Besides, palmarosa is beneficial for cardiovascular system, circulation, digestion, infection, nervous system and rashes (Lawrence et al.,2012) skin care, and beauty treatments (Thaker, et al., 2009). Palmarosa possesses various pharmacological activities such as antibacterial, anti-fungal and anti-inflammatory properties (Karkala et al., 2014). Its essential oil also used in perfumery industries.

In agricultural crops grown under rainfed condition; a number of agronomic practices have been developed to improve the quality production of palmarosa. It can propagate by through both seeds and tillers in our country, Palmarosa grown and its herb have been used for various purposes. It is one of the priority aromatic plants in 
Ethiopia and two varieties have been released so far. There were many factors that influence the agronomic characteristics, biomass and EO yield of aromatic plant (Mohammad S., 2009). However, so many factors affect production of Palmarosa among which number slips /tillers/ during planting play great role. Besides, conducive number of slips /tillers/ used for planting was not fully studied in the country. The present investigation was carried out with the objectives of testing the number of tillers for the two variety of palmarosa to increasing the biomass and essential oil yields of palmarosa.

\section{Objective:}

$>$ To assess the role of number of tillers on quality production of palma rosa grass varieties.

\section{Materials and Methods}

\section{Site discretion}

The experiment has been conducted during 2019 in the research field of Wondogenet agricultural research center. Wendo genet is located at $7^{\circ} 192 \mathrm{~N}$ latitude and $38^{\circ} 382 \mathrm{E}$ longitude with altitude of $1780 \mathrm{~m}$ a.s.1. The site receives mean annual rainfall of $1128 \mathrm{~mm}$ with minimum and maximum temperature of 11.47 and $26.51{ }^{\circ} \mathrm{C}$, respectively. The soil textural area of the experimental area was sandy loam with the $\mathrm{pH}$ of 7.2 (Abayneh et al. 2006). The Wgtejisar-1 and Wg-tejisar-1, varieties which were adaptable to the experimental area were used as planting material.

\section{Treatments and Experimental Design}

The experiment was laid out in randomized complete block design (RCBD) in a factorial arrangement with three replications. Treatment consists of 3, 5, 7, and 9 numbers of tillers which were propagated vegetatively through slips obtained by the splitting up of individual adult clumps. and two palmarosa grass varieties (Wg-tejisar-1 and Wg-tejisar-1). Thus, there was $4 \times 2$ (8) treatment combination. The plot size was $3 \times 3 \mathrm{~m}$ with area of $9 \mathrm{~m}^{2}$ and spacing of $60 \mathrm{~cm}$ between hills and rows was maintained during the experiment resulting five rows and five plants per plot. Respective spacing of $1.5 \mathrm{~m}$ and $1 \mathrm{~m}$ was maintained between any two replications and plots respectively. Healthy slips from well grown clumps of palmarosa grass maintained at wondo Genet Agricultural Research Center were used for planting in well prepared experimental field. No fertilizer and chemical pesticide applied during experiment. All required cultural practices done as required. All agronomic practices of the experimental field were carried out uniformly whenever required.

To determine the yield and agronomic characteristics of palmarosa under planting different number of tillers and palmarosa variety, plant height, number of leaves, number of tillers, fresh biomass (Qt/ha), oil content (\%), essential oil $(\mathrm{kg} / \mathrm{ha})$ and survival count $/ 1 \mathrm{~m}^{2}$ of palmarosa were collected. Throughout the experimental period, each parameter was collected two times within three months interval starting from planting.

\begin{tabular}{|l|l|l|l|l|}
\hline No & $\begin{array}{l}\text { Factor A (palmarosa } \\
\text { variety) }\end{array}$ & $\begin{array}{l}\text { Factor B (number of } \\
\text { tillers) }\end{array}$ & Combination & Treatment code \\
\hline 1 & WG-Tejsar-I & 3 tillers & WG-Tejsar-I + 3 tillers & T1 \\
\hline 2 & WG-Tejsar-I & 5 tillers & WG-Tejsar-I + 5 tillers & T2 \\
\hline 3 & WG-Tejsar-I & 7 tillers & WG-Tejsar-I + 7 tillers & T3 \\
\hline 4 & WG-Tejsar-I & 9 tillers & WG-Tejsar-I + 9 tillers & T4 \\
\hline 5 & WG-Tejsar-II & 3 tillers & WG-Tejsar-II+ 3 tillers & T5 \\
\hline 6 & WG-Tejsar-II & 5 tillers & WG-Tejsar-II+ 7 tillers & T7 \\
\hline 7 & WG-Tejsar-II & 7 tillers & WG-Tejsar-II+9 tillers & T8 \\
\hline 8 & WG-Tejsar-II & 9 tillers & WG-Tejsar-I and WG-Tejsar-II) and the \\
\hline
\end{tabular}

Table 1 Treatment combinations of the two Palma Rosa variety (WG-Tejsar-I and WG-Tejsar-II) and the four different number of tillers.

\section{Statistical Data Analysis}

The data recorded in this study was subjected to statistical analysis. The analysis of variance was carried out using SAS software. Significance differences between treatment means was delineated by least significance difference (LSD) test at $5 \%$ level of significance.

\section{Result and Discussion: \\ Plant Height}

The first cycle data was taken three months later after planting. The longest plant recorded at the plot which contain WG-Tejsar-II variety with planting seven tillers $(44.00 \mathrm{~cm})$ and next to that planting WG-Tejsar-I variety with three number of tillers shows the longest height as compare to the other treatment. Even if no significant difference the effects of planting 7 and 3 tillers for WG-Tejsar-II and WG-Tejsar-I verities respectively have better plant height as compare to planting 5 and 9 number of tillers. So, planting the two palmarosa verities with the number 
of 3 tillers is the most advantageous from the other choice of tiller levels. Generally, the average plant height at WG-Tejsar-I variety showed that the longest plant height as compare to WG-Tejsar-II variety at all levels of tillers. The second cycle data was recorded after six months after planting and the plant height was not affected by varying the level of tillers number but the value indicated that planting seven tillers for the two palmarosa varieties shows the longest relative to the rest of configured levels. Here the plant height of WG-Tejsar-I recorded for each levels of tillers were uniform as compare to the variety of WG-Tejsar-II. In general, this result indicated that the plant height of palmarosa could not be affected by the number of tillers.

Table 2: Main effect of palmarosa varieties and number of tillers on plant height, number of leaves and number of tillers at the first cycle.

\begin{tabular}{|l|l|l|l|l|}
\hline No & Treatments & Plant height & Number of leaves & Number of tillers \\
\hline 1 & WG-Tejsar-I + 3 tillers & $40.33 \mathrm{ab}$ & $101.67 \mathrm{ab}$ & $22.00 \mathrm{ab}$ \\
\hline 2 & WG-Tejsar-I + 5 tillers & $37.33 \mathrm{ab}$ & $101.00 \mathrm{ab}$ & $26.00 \mathrm{ab}$ \\
\hline 3 & WG-Tejsar-I+ 7 tillers & $39.67 \mathrm{ab}$ & $101.33 \mathrm{ab}$ & $30.33 \mathrm{ab}$ \\
\hline 4 & WG-Tejsar-I + 9 tillers & $38.67 \mathrm{ab}$ & $92.67 \mathrm{~b}$ & $24.67 \mathrm{ab}$ \\
\hline 5 & WG-Tejsar-II+ 3 tillers & $37.67 \mathrm{ab}$ & $113.00 \mathrm{ab}$ & $29.00 \mathrm{ab}$ \\
\hline 6 & WG-Tejsar-II + 5 tillers & $34.00 \mathrm{~b}$ & $66.00 \mathrm{~b}$ & $17.00 \mathrm{~b}$ \\
\hline 7 & WG-Tejsar-II+ 7 tillers & $44.00 \mathrm{a}$ & $164.00 \mathrm{a}$ & $51.33 \mathrm{a}$ \\
\hline 8 & WG-Tejsar-II+ 9 tillers & $31.67 \mathrm{~b}$ & $110.00 \mathrm{ab}$ & $32.00 \mathrm{ab}$ \\
\hline LSD & & $\mathbf{9 . 8 0}$ & $\mathbf{6 4 . 9 8}$ & $\mathbf{2 0 . 3 3}$ \\
\hline Sig & $\mathbf{N S}$ & $\mathbf{N S}$ & $\mathbf{N S}$ \\
\hline CV & $\mathbf{1 5 . 0 5}$ & $\mathbf{3 4 . 9 4}$ & $\mathbf{3 9 . 9 7}$ \\
\hline
\end{tabular}

Table 3: Main effect of palmarosa varieties and number of tillers on plant height, number of leaves and number of tillers at the second cycle.

\begin{tabular}{|l|l|l|l|l|}
\hline No & Treatments & Plant height & Number of leaves & Number of tillers \\
\hline 1 & WG-Tejsar-I + 3 tillers & $33.33 \mathrm{a}$ & $84.46 \mathrm{a}$ & $37.21 \mathrm{a}$ \\
\hline 2 & WG-Tejsar-I + 5 tillers & $33.06 \mathrm{a}$ & $68.18 \mathrm{a}$ & $33.46 \mathrm{a}$ \\
\hline 3 & WG-Tejsar-I+ 7 tillers & $34.37 \mathrm{a}$ & $86.02 \mathrm{a}$ & $37.37 \mathrm{a}$ \\
\hline 4 & WG-Tejsar-I + 9 tillers & $31.45 \mathrm{a}$ & $70.46 \mathrm{a}$ & $27.52 \mathrm{a}$ \\
\hline 5 & WG-Tejsar-II+ 3 tillers & $30.74 \mathrm{a}$ & $76.40 \mathrm{a}$ & $32.70 \mathrm{a}$ \\
\hline 6 & WG-Tejsar-II + 5 tillers & $28.29 \mathrm{a}$ & $56.63 \mathrm{a}$ & $27.79 \mathrm{a}$ \\
\hline 7 & WG-Tejsar-II+ 7 tillers & $36.74 \mathrm{a}$ & $71.66 \mathrm{a}$ & $35.39 \mathrm{a}$ \\
\hline 8 & WG-Tejsar-II+9 tillers & $34.10 \mathrm{a}$ & $73.19 \mathrm{a}$ & $29.46 \mathrm{a}$ \\
\hline LSD & & $\mathbf{9 . 3 4}$ & $\mathbf{3 4 . 1 5}$ & $\mathbf{1 9 . 9 0}$ \\
\hline Sig & $\mathbf{N S}$ & $\mathbf{N S}$ & $\mathbf{N S}$ \\
\hline CV & $\mathbf{1 6 . 2 8}$ & $\mathbf{2 6 . 5 8}$ & $\mathbf{3 4 . 8 4}$ \\
\hline
\end{tabular}

\section{Number of Leaves per hill}

The highest number of leaves was recorded by planting WG-Tejsar-II palmarosa variety with 7 tillers while the small number of leaves was recorded by planting the same variety of palmarosa with 5 tiller number. For each variety the highest number of leaves was showed by planting 7 tillers and the value of leaf number at WG-TejsarI showed uniform than the variety of WG-Tejsar-II. So, planting 3 tillers for the WG-Tejsar-I and 7 tillers for the variety of WG-Tejsar-II makes advantageous to get a greater number of leaves per hill.

Six months later after planting the number of tillers did not show significant effect on the number of leaves but the recorded value indicated that the variety WG-Tejsar-I has greater capacity to regenerate than the variety WG-Tejsar-II. In general, according to the second time data record planting 3 tillers at a time have an advantage to get a greater number of leaves for the two variety of palmarosa. Similarly, fewer tiller number per planting slip resulted higher leaf number per hill than more tiller number per planting slip treatments as reported by Werotaw (2019).

\section{Number of tillers}

The maximum number of tillers was recorded by planting seven tillers with the varieties of WG-Tejsar-I and WGTejsar-II respectively whereas the minimum number of tillers recorded from the plot which contains the treatment of WG-Tejsar-I with three number of tillers and WG-Tejsar-II with five tillers. The palmarosa with variety of WGTejsar-II is responsive for the number of tiller than the variety WG-Tejsar-I.

The second time data collection after six months after planting, the number of tillers had no difference in its value but planting seven tillers have the highest number of tillers for the two palma rosa variety but which was slightly different from planting three tillers. According to the recorded data in the two cycle the number of tillers 
could be slight influence on the emerging tillers at early stage than at the older stage. In general planting three number of tillers have an advantageous than the other choice of tiller number to grow a greater number of tillers, the result of Werotaw (2019) also revealed that as number of tillers per planting slip increased from one to four, number of tillers per plant significantly decreased.

\section{Fresh biomass}

The highest weight of fresh biomass was harvested by planting WG-Tejsar-II variety with seven tillers $(83.88$ Qt/ha) planting which have no biomass difference with planting the variety with three number of tillers, similar finding obtained by Werotaw (2019) stated that significantly higher value were resulted at one tiller number per planting slip treatment. Similar results were obtained by Linares et al (2005) who reported that wider spacing gave higher herb yield per plant which might be attributed to the opportunity of wider-spaced plants to increase the synthesis of metabolites, resulting in growth of more stems and roots. On the other hand, planting WG-Tejsar-II variety with seven tillers have a greater biomass than the other choice of tiller numbers which also have a significant biomass production as compared to the variety of WG-Tejsar-I and number of tillers combination. According to the first harvesting data the variety of WG-Tejsar-II was more influenced by the number of tillers than the variety of WG-Tejsar-I. There is fluctuated biomass record at the variety of WG-Tejsar- II as compared to WG-Tejsar-I.

At the second cycle of data recording planting of nine tillers for the two varieties of palmarosa showed that the lowest biomass production whereas significantly higher biomass was recorded by planting WG-Tejsar-I with three number of tillers (49.59 Qt/ha) which was greater even WG-Tejsar-II with all number of tillers combinations. Generally planting WG-Tejsar-I varieties with three and seven number of tillers ranked first and second in biomass production respectively. According to the analyzed data the fresh biomass of palmarosa could be affected by the number of tillers and some weight fluctuating at the variety of WG-Tejsar-II as compare to WG-Tejsar-I, here is somewhat uniform and higher fresh biomass weight was recorded. The result indicated that the fresh biomass of palmarosa was higher due to the number of tillers within three months growing time and shows decreasing trend at the second harvesting time. According to Zewdinesh and Beemnet (2012) report there was a decreasing trend of dry herbage yield with increasing age of palmarosa.

Table 4: Main effect of palmarosa varieties and number of tillers on fresh biomass, essential oil and survival count at the first cycle.

\begin{tabular}{|l|l|l|l|l|l|}
\hline No & Treatments & $\begin{array}{l}\text { Fresh biomass in } \\
\text { Qt/ha }\end{array}$ & $\begin{array}{l}\text { Essential oil } \\
\text { content in \% }\end{array}$ & $\begin{array}{l}\text { Essential oil yield } \\
\mathrm{kg} / \mathrm{ha}\end{array}$ & Survival count \\
\hline 1 & WG-Tejsar-I + 3 tillers & $45.91 \mathrm{bc}$ & $0.99 \mathrm{~b}$ & $49.61 \mathrm{c}$ & $1.88 \mathrm{a}$ \\
\hline 2 & WG-Tejsar-I + 5 tillers & $43.51 \mathrm{c}$ & $1.46 \mathrm{ab}$ & $69.95 \mathrm{abc}$ & $2.29 \mathrm{a}$ \\
\hline 3 & WG-Tejsar-I+7 tillers & $42.41 \mathrm{c}$ & $1.37 \mathrm{ab}$ & $61.79 \mathrm{bc}$ & $1.57 \mathrm{a}$ \\
\hline 4 & WG-Tejsar-I + 9 tillers & $53.93 \mathrm{bc}$ & $1.24 \mathrm{ab}$ & $69.39 \mathrm{abc}$ & $1.88 \mathrm{a}$ \\
\hline 5 & WG-Tejsar-II+ 3 tillers & $70.52 \mathrm{ab}$ & $1.79 \mathrm{a}$ & $102.34 \mathrm{ab}$ & $2.19 \mathrm{a}$ \\
\hline 6 & WG-Tejsar-II + 5 tillers & $30.29 \mathrm{c}$ & $1.23 \mathrm{ab}$ & $36.11 \mathrm{c}$ & $2.19 \mathrm{a}$ \\
\hline 7 & WG-Tejsar-II+ 7 tillers & $83.88 \mathrm{a}$ & $1.37 \mathrm{ab}$ & $115.49 \mathrm{a}$ & $2.50 \mathrm{a}$ \\
\hline 8 & WG-Tejsar-II+9 tillers & $54.50 \mathrm{bc}$ & $1.55 \mathrm{ab}$ & $80.62 \mathrm{abc}$ & $1.67 \mathrm{a}$ \\
\hline LSD & $\mathbf{2 5 . 2 6}$ & $\mathbf{0 . 5 9}$ & $\mathbf{4 7 . 1 5}$ & $\mathbf{1 . 1 5}$ \\
\hline Sig & $*$ & $\mathbf{N S}$ & $*$ & $\mathbf{N S}$ \\
\hline CV & $\mathbf{2 7 . 1 6}$ & $\mathbf{2 4 . 6 2}$ & $\mathbf{3 6 . 8 0}$ & $\mathbf{3 2 . 5 2}$ \\
\hline
\end{tabular}

Table 5: Main effect of palmarosa varieties and number of tillers on fresh biomass, essential oil and survival count at the second cycle.

\begin{tabular}{|l|l|l|l|l|l|}
\hline No & Treatments & $\begin{array}{l}\text { Fresh biomass in } \\
\text { Qt/ha }\end{array}$ & $\begin{array}{l}\text { Essential oil } \\
\text { content in \% }\end{array}$ & $\begin{array}{l}\text { Essential oil } \\
\text { production kg/ha }\end{array}$ & Survival count \\
\hline 1 & WG-Tejsar-I + 3 tillers & $49.59 \mathrm{a}$ & $1.04 \mathrm{a}$ & $62.54 \mathrm{a}$ & $2.08 \mathrm{ab}$ \\
\hline 2 & WG-Tejsar-I + 5 tillers & $30.30 \mathrm{~b}$ & $1.10 \mathrm{a}$ & $38.03 \mathrm{abc}$ & $2.29 \mathrm{a}$ \\
\hline 3 & WG-Tejsar-I+ 7 tillers & $33.07 \mathrm{~b}$ & $1.17 \mathrm{a}$ & $40.71 \mathrm{abc}$ & $2.19 \mathrm{ab}$ \\
\hline 4 & WG-Tejsar-I + 9 tillers & $25.44 \mathrm{~b}$ & $1.11 \mathrm{a}$ & $28.20 \mathrm{c}$ & $1.98 \mathrm{ab}$ \\
\hline 5 & WG-Tejsar-II+ 3 tillers & $31.48 \mathrm{~b}$ & $1.11 \mathrm{a}$ & $35.19 \mathrm{bc}$ & $0.94 \mathrm{~b}$ \\
\hline 6 & WG-Tejsar-II + 5 tillers & $24.60 \mathrm{~b}$ & $1.37 \mathrm{a}$ & $33.93 \mathrm{bc}$ & $1.67 \mathrm{ab}$ \\
\hline 7 & WG-Tejsar-II+7 tillers & $32.30 \mathrm{~b}$ & $1.71 \mathrm{a}$ & $56.68 \mathrm{ab}$ & $1.87 \mathrm{ab}$ \\
\hline 8 & WG-Tejsar-II+9 tillers & $22.17 \mathrm{~b}$ & $1.47 \mathrm{a}$ & $30.76 \mathrm{c}$ & $1.36 \mathrm{ab}$ \\
\hline LSD & & $\mathbf{1 1 . 8 0}$ & $\mathbf{0 . 8 4}$ & $\mathbf{2 5 . 0 5}$ & $\mathbf{1 . 2 8}$ \\
\hline Sig & & $\mathbf{N S}$ & $\mathbf{N S}$ & $\mathbf{N S}$ \\
\hline CV & & $\mathbf{2 1 . 6 4}$ & $\mathbf{3 8 . 0 2}$ & $\mathbf{3 5 . 1 1}$ & $\mathbf{4 0 . 5 3}$ \\
\hline
\end{tabular}




\section{Essential Oil content $(\%)$}

According to the first cycle data the heights oil content recorded at the plot which contain WG-Tejsar-II variety with planting three tillers $(1.79 \%)$ and next to that planting WG-Tejsar-II variety with nine number of tillers $(1.55 \%)$ shows the heights oil content as compare to the other treatment. Even if no significant difference between the recorded oil content, the effects of planting 3 tillers on the WG-Tejsar-II verities have better essential oil content as compare to planting 5, 7 and 9 number of tillers. Similarly, the higher essential oil content was obtained at one tiller number per planting slip treatment and had reducing trend as number of tillers per planting slip increased Werotaw (2019). Because of non-significant oil content, planting the two verities with the number of 3 tillers is the most advantageous from the other choice of tiller number. Generally, the average oil content of WGTejsar-II variety showed that the better oil content as compare to WG-Tejsar-I variety.

The second cycle data was recorded after six months and the oil content was not affected by varying the level of tillers number however the value indicated that planting seven tillers for the WG-Tejsar-II (1.71\%) and five tillers for the WG-Tejsar-I (1.47\%) varieties ranked first and second in oil content relative to the rest of configured tiller number respectively. Here the oil content of WG-Tejsar- I recorded for each levels of tillers were uniform as compare to the variety of WG-Tejsar-II. In general, the result indicated that the oil content of palmarosa could not be affected by the number of tillers within three months growing time but above three months the oil content decreases as compare to the first harvesting time. Regarding the effect of agricultural practices on quality of lemongrass oil, in the first cut the highest citral concentration was determined by cultivation at wider row spacing followed by narrow row spacing over control plants as stated by Emad et al (2017).

\section{Essential Oil Yield (kg/ha)}

The first cycle data was taken three months later after planting. The heights yield of oil recorded at the plot which contain WG-Tejsar-II variety with planting seven tillers $(115.49 \mathrm{~kg} / \mathrm{ha})$ and next to that planting WG-Tejsar-II variety with three number of tillers $(102.34 \mathrm{~kg} / \mathrm{ha})$ shows the heights yield of oil as compare to the other treatment. According to the combined effect of the variety and tiller number there was significant difference between the recorded oil yield and the effects of planting 7 and 3 tillers on the WG-Tejsar-II verities have better essential oil as compare to planting 5 and 9 number of tillers. Because of non-significant weight of oil yield, planting the two verities with the number of 3 tillers is the most advantageous from the other choice of tiller levels. Similarly, Emad et al (2017) reviled that the effect of planting density, in both seasons, the significantly highest oil yield per plant was obtained by wider spacing in the first cut. Generally, the average oil production of WG-Tejsar-II variety showed that the better weight as compare to WG-Tejsar-I variety at all levels of tillers except tiller number five. The second cycle data was recorded six months after planting and the oil yield was not affected by varying the number of tillers but the value indicated that planting three tillers for the WG-Tejsar-I $(62.54 \mathrm{~kg} / \mathrm{ha})$ and seven tillers for the WG-Tejsar-I varieties $(56.68 \mathrm{~kg} / \mathrm{ha})$ ranked first and second in oil yield relative to the rest of configured tiller number respectively. Here the oil yield of WG-Tejsar- II recorded for each levels of tillers were uniform as compare to the variety weight of WG-Tejsar-I. On the other hand, the highest and the lowest oil volume were recorded at the variety of WG-Tejsar-I. In general, the combined effect indicated that the oil yield of palmarosa could not be affected by the number of tillers at the two-cycle harvesting time. The average oil yield at the second cycle decreases as compare to the first harvesting time.

\section{Survival count}

The highest number of survived tillers were counted by planting WG-Tejsar- II variety with 7 tillers which have no survival difference with all palmarosa variety and number of tillers combination. On the other hand, the variety WG-Tejsar-II have a greater capacity to survive even as compared to the variety of WG-Tejsar-I. Even if no significant difference the variety of WG-Tejsar-I was more influenced by the number of tillers than the variety of WG-Tejsar- II.

At the second cycle of data recording time planting of 7 tillers for the WG-Tejsar-II and planting of 9 tillers for the same variety of palmarosa showed that the highest and the lowest survival count respectively in $1 \mathrm{~m}^{2}$ area. The survival count was higher by planting 7 tillers at the first cycle and the same is true in the second cycle harvesting. The survival count at the two cycle all most the same so it is better to use 7 tillers with the tow variety. According to the analyzed data the survival count of palmarosa could not be affected by the number of tillers however some fluctuating at the variety of WG-Tejsar-I as compare to WG-Tejsar-II.

\section{Summery and Conclusion}

The first cycle data was taken three months later after planting. Even if no significant difference the effects of planting 7 and 3 tillers for WG-Tejsar-II and WG-Tejsar-I verities have better plant height, number of leaves as compare to planting 5 and 9 number of tillers respectively. The highest number of tillers was recorded by planting 7 tillers with the varieties of WG-Tejsar-I and WG-Tejsar-II respectively whereas the lowest number of tillers recorded from the plot which contains the treatment of WG-Tejsar-I with 3 number of tillers and WG-Tejsar-II 
with 5 tillers. Significantly highest fresh biomass yield was harvested by planting WG-Tejsar-II variety with 7 tillers $(83.88 \mathrm{Qt} / \mathrm{ha})$ which have no biomass difference with planting the variety with 3 number of tillers. The maximum oil content recorded at the plot which contain WG-Tejsar-II variety with planting 3 tillers $(1.79 \%)$ and next to that planting WG-Tejsar-II variety with 9 number of tillers $(1.55 \%)$ shows the heights oil content as compare to the other treatment. The maximum yield of oil recorded at the plot which contain WG-Tejsar-II variety with planting 7 tillers $(115.49 \mathrm{~kg} / \mathrm{ha})$ and next to that planting WG-Tejsar-II variety with 3 number of tillers $(102.34 \mathrm{~kg} / \mathrm{ha})$ shows the heights yield of oil as compare to the other treatment.

The second cycle data was recorded six months after planting and similarly plant height, number of leaves and tillers were not affected by varying number tillers but the value indicated that planting 7 tillers for the two palmarosa varieties shows the longest and the highest number of tillers relative to the rest of configured levels. On the other hand, planting 3 tillers at a time have an advantage to get a greater number of leaves for the two variety of palmarosa. Planting of 9 tillers for the two varieties of palmarosa showed that the lowest biomass production whereas significantly higher biomass was recorded by planting WG-Tejsar-I with 3 number of tillers (49.59 Qt/ha) which was greater even WG-Tejsar-II with all number of tillers combinations. The oil content was not affected by varying the level of tillers number however the value indicated that planting 7 tillers for the WG-Tejsar-II (1.71\%) and five tillers for the WG-Tejsar-I $(1.47 \%)$ varieties ranked first and second in oil content relative to the rest of configured tiller number respectively. The oil yield was not affected by varying the number of tillers but the value indicated that planting 3 tillers for the WG-Tejsar-I $(62.54 \mathrm{~kg} / \mathrm{ha})$ and 7 tillers for the WG-Tejsar-I varieties $(56.68$ $\mathrm{kg} / \mathrm{ha}$ ) ranked first and second in oil yield relative to the rest of configured tiller number respectively. This result revealed that the oil yield might be changed due to biomass yield rather than the content of the treatments. In general planting WG-Tejsar-II and WG-Tejsar-I variety with 7 and 3 tillers had an advantage for vegetative as well as quantitative palmarosa production respectively.

\section{Reference}

1. Abayneh E, Demeke T, Ashenafi A (2006). Soils of Wendo Gent Agricultural Research Center, National soil Research Center, Addis Ababa Ethiopia, 67 pp.

2. Emad S Hamed, Wael I. M. T and Mona El-Shazly (2017). Effect of planting density and biofertilization on growth and productivity of Cymbopogon citratus (DC.) Stapf. (Lemongrass) plant under Siwa Oasis conditions. Journal of Medicinal Plants Studies; 5(2): 195-203.

3. Kapil L, Reena L, Dharmendra K. P. and Rashmi Srivastava (2012). Anioxidant activity of palmarosa essential oil (Cymbopogon martini) grown in north indian plains, ResearchGate.

4. Karkala M. and Bhushan B. (2014). Review on pharmacological activity of Cymbopogon citratus, International Journal of Herbal Medicine 2014; ISSN 2321-2187, 1 (6): 5-7.

5. Linares S, Gonzalez N, Gómez E, Usubillaga A. and Darghan E. (2005). Effect of the fertilization, plant density and time of cutting on yield and quality of the essential oil of Cymbopogon citratus Stapf. Rev. Fac. Agron. (LUZ); 22:247-260.

6. M. H. LODHIA, K. R. BHATT And V. S. THAKeR* (2009). Antibacterial Activity of Essential Oils from Palmarosa, Evening Primrose, Lavender and Tuberose, Indian Journal of Pharmaceutical Sciences, Department of Biosciences, Saurashtra University, Rajkot-360 005, India.

7. Mohammad S. Abu-darwish, EzzAL-DeinAl-Ramamneh (2009), The present-day Survey of Registered and Standardized Herbal Medicinesin Jordanian Pharmaceutical Market, Am.-EurasianJ.Sustain.Agric., ISSN1995-0748.

8. Smitha G, Ponnuchamy M. and Thania S. Varghese (2015). Cultivation of Palmarosa. ResearchGate.

9. Takankhar, V. G., Karanjikar, P. N., Gutte, A. V. and Bhoye, S. R (2017). IRRIGATION AND NITROGEN MANAGEMENT IN PALMAROSA, International Journal of Current Research Vol. 9, Issue, 11, pp.6100561007, November, 2017.

10. Werotaw S. Yeshitila (2019). Herbage and Essential Oil Yield of Two Lemmon Grass (Cymbopogon Citratus) Varieties as Affected by Harvesting Cycle and Number of Tillers Per Planting Slips at Wondo Genet,Southern Ethiopia. International Journal of Research Studies in Agricultural Sciences (IJRSAS), Volume 5, Issue 2, 2019, PP 18-22, ISSN No. (Online) 2454-6224.

11. Zewdnesh D. Zigene and Beemnet M. Kasahun (2012). Agronomic Characteristics and Essencial Oil Yield of Palmarosa (Cymbopogon Martinii (Roxb.) Wats) as Affected by Population Dencity and Harvesting Age at Wondo Genet, Souther Ethiopia. The African Jornal of Plant Science and Biothechnology. 